\title{
NADPH biosensor-based identification of an alcohol dehydrogenase variant with improved catalytic properties caused by a single charge reversal at the protein surface
}

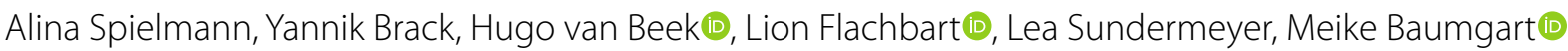 \\ and Michael Bott ${ }^{*}$ (i)
}

\begin{abstract}
Alcohol dehydrogenases (ADHs) are used in reductive biotransformations for the production of valuable chiral alcohols. In this study, we used a high-throughput screening approach based on the NADPH biosensor pSenSox and fluorescence-activated cell sorting (FACS) to search for variants of the NADPH-dependent ADH of Lactobacillus brevis $(L b A D H)$ with improved activity for the reduction of 2,5-hexanedione to $(2 R, 5 R)$-hexanediol. In a library of approx. $1.4 \times 10^{6}$ clones created by random mutagenesis we identified the variant $\angle b A D H^{K 71 E}$. Kinetic analysis of the purified enzyme revealed that $L b A D H^{K 71 E}$ had a 16\% lowered $K_{M}$ value and a $17 \%$ higher $V_{\max }$ for 2,5-hexanedione compared to the wild-type $\mathrm{LbADH}$. Higher activities were also observed for the alternative substrates acetophenone, acetylpyridine, 2-hexanone, 4-hydroxy-2-butanone, and methyl acetoacetate. $K 71$ is solvent-exposed on the surface of $L b A D H$ and not located within or close to the active site. Therefore, $\mathrm{K} 71$ is not an obvious target for rational protein engineering. The study demonstrates that high-throughput screening using the NADPH biosensor pSenSox represents a powerful method to find unexpected beneficial mutations in NADPH-dependent alcohol dehydrogenases that can be favorable in industrial biotransformations.
\end{abstract}

Keywords: NADPH biosensor, Lactobacillus brevis, NADPH-dependent alcohol dehydrogenase, Enzyme optimization, Fluorescence-activated cell sorting, Random mutagenesis

\section{Introduction}

Chiral alcohols with high enantiomeric purity are important intermediates for the synthesis of optically active fine chemicals that are used for example to produce pharmaceuticals and agrochemicals (Ager et al. 1996; Liese et al. 2006; Breuer et al. 2004). Alcohol dehydrogenases (ADHs) are used for the synthesis of chiral alcohols under very mild reaction conditions due to their high catalytic efficiency and selectivity (Hall and Bommarius 2011; Zheng et al. 2017). A prominent example

*Correspondence: m.bott@fz-juelich.de

IBG-1: Biotechnology, Institute of Bio- and Geosciences,

Forschungszentrum Jülich, Jülich, Germany is the NADPH-dependent ADH from Lactobacillus brevis (LbADH), which catalyzes the stereoselective reduction of prochiral ketones to the corresponding, mostly $(R)$-configured secondary alcohols (Hummel 1999; Rodriguez et al. 2014). $\mathrm{LbADH}$ is an attractive candidate for biotransformations because it is a robust and versatile biocatalyst with high regio- and stereoselectivity, a broad substrate range, and the ability to convert sterically demanding substrates (Leuchs and Greiner 2011). Its preferred substrates are prochiral ketones such as acetophenone with almost invariably a small methyl group as one substituent and a bulky (often aromatic) moiety (such as phenyl) as the other (Schlieben et al. 2005). The efficiency of substrate conversion by $\mathrm{LbADH}$ is influenced 
by the substrate size, the steric and electronic effects of the substrate as well as the thermodynamic stability of the products (Rodriguez et al. 2014). $\mathrm{LbADH}$ is active as a homotetramer with 251 amino acid residues and a molecular mass of $26.6 \mathrm{kDa}$ per subunit (Riebel 1997; Niefind et al. 2003). It is a short-chain $\mathrm{Mg}^{2+}$-dependent reductase that uses the NADPH as cofactor. The crystal structure of $L b A D H$ has been solved (Niefind et al. 2003; Schlieben et al. 2005). The non-covalently bound cofactor NADPH is essential for catalysis and must be recycled efficiently to make the biotransformation economically feasible (Leuchs and Greiner 2011; Döbber et al. 2018).

Because of the industrial relevance of ADHs, their improvement for various applications is of high interest, such as the optimization of specificity or catalytic activity or the broadening of the substrate spectrum (Hall and Bommarius 2011). The approaches used for obtaining improved $\mathrm{ADH}$ variants, such as directed evolution or rational design, have recently been reviewed (Zhang et al. 2015). In directed evolution, a large number of variants of a particular enzyme created by random and/or targeted mutagenesis is screened for the desired property (Farinas et al. 2001). However, the success of this approach is often restricted by the lack of an efficient high-throughput (HT) screening assay. Typically, screenings of mutant libraries involve dedicated assays for a certain substrate or product, because the majority of molecules of interest do not lead to an easily observable phenotype (Bloch 2006). In the case of ADHs, the consumption or production of $\mathrm{NAD}(\mathrm{P}) \mathrm{H}$ can be measured or colorimetric assays can be employed (Zhang et al. 2015), but this limits the number of variants that will be tested e.g. in 384-well microtiter plates in practice to $10^{4}-10^{5}$. Fluorescenceactivated cell sorting (FACS) allows screening of up to 80,000 single cells per second and thus enables HTscreening of $10^{7}-10^{9}$ variants, if an $\mathrm{ADH}$ assay suitable for FACS is available (van Rossum et al. 2013).

Genetically encoded biosensors based on transcription factors controlling the synthesis of a fluorescent reporter protein are highly useful tools for HT-screening in strain and enzyme development (Dietrich et al. 2010; Eggeling et al. 2015; Mahr and Frunzke 2016; Rogers et al. 2016). We previously reported a transcription factor-based NADPH biosensor allowing HT-screening of $\mathrm{NADPH}$-dependent enzymes via fluorescence-activated cell sorting (FACS) of an Escherichia coli-based mutant library (Siedler et al. 2014). The NADPH biosensor is encoded by the plasmid pSenSox and consists of the transcription factor SoxR, its target promoter $\mathrm{P}_{\text {soxs }}$, and the reporter gene eyfp. The SoxRS system of $E$. coli triggers the response to oxidative stress (Greenberg et al. 1990; Tsaneva and Weiss 1990) and SoxR was found to be activated, besides other stimuli, by a reduction of the
$\mathrm{NADPH} / \mathrm{NADP}^{+}$ratio in the cell (Liochev and Fridovich 1992; Krapp et al. 2011). We recently confirmed that the pSenSox biosensor responds to various NADPH-related processes in E. coli, such as the presence of redox-cycling drugs, the absence of the SoxR-reducing proteins RsxABCDGE and $\mathrm{RseC}$, and the absence of the transhydrogenases PntAB and/or SthA (Spielmann et al. 2018).

Escherichia coli cells carrying pSenSox become fluorescent during NADPH-dependent biotransformation processes due to a high rate of NADPH consumption. Using the reduction of methyl acetoacetate to $R$-methyl 3-hydroxybutyrate by $L b \mathrm{ADH}$ as model reaction, it was demonstrated that the specific eYFP fluorescence of cells correlates both with the substrate concentration and, when the substrate concentration is kept constant, with the specific LbADH activity (Siedler et al. 2014). Due to the latter property, one promising application of the NADPH biosensor is the FACS-based HT-screening of libraries with a high number of variants of NADPHdependent enzymes. A proof of concept approach led to the identification of an $L b A D H$ variant with a slightly increased activity, but reduced affinity for the substrate 4-methyl-2-pentanone (Siedler et al. 2014).

In the present study, we applied the pSenSox biosensor to screen an LbADH library in E. coli by FACS for variants that enable an improved biotransformation of 2,5-hexanedione to $(2 R, 5 R)$-hexanediol. This compound serves as a building block for the synthesis of fine chemicals, pharmaceuticals, agrochemicals and chiral phosphine ligands (Haberland et al. 2002; Machielsen et al. 2009). We identified the variant $L b \mathrm{ADH}^{\mathrm{K} 71 \mathrm{E}}$ and showed that it has an increased activity for the reduction of 2,5-hexanedione, but also various other substrates.

\section{Materials and methods}

\section{Chemicals, bacterial strains, plasmids and growth conditions}

Unless specified otherwise the chemicals were purchased from Sigma-Aldrich $\mathrm{GmbH}$ (Steinheim, Germany), BD Biosciences (Franklin Lakes, USA), or Carl Roth (Karlsruhe, Deutschland). All bacterial strains and plasmids used in this work are listed in Table 1. One Shot ${ }^{\mathrm{TM}}$ TOP10 Electrocomp E. coli cells (Invitrogen, Karlsruhe, Germany) were used for cloning and screening purposes. Transformation of $E$. coli cells was performed as described (Hanahan 1983). Cells were cultivated at $37^{\circ} \mathrm{C}$ in liquid 2xTY medium consisting of $16 \mathrm{~g} \mathrm{~L}^{-1}$ tryptone (BD Biosciences, Franklin Lakes, USA), $10 \mathrm{~g} \mathrm{~L}^{-1}$ yeast extract, and $5 \mathrm{~g} \mathrm{~L}^{-1}$ sodium chloride, in terrific broth (TB) medium $\left(12 \mathrm{~g} \mathrm{~L}^{-1}\right.$ tryptone, $24 \mathrm{~g} \mathrm{~L}^{-1}$ yeast extract, $4 \mathrm{~mL}$ glycerol, $12.54 \mathrm{~g} \mathrm{~L}^{-1} \mathrm{~K}_{2} \mathrm{HPO}_{4}$, $2.31 \mathrm{~g} \mathrm{~L}^{-1} \mathrm{KH}_{2} \mathrm{PO}_{4}$; $\mathrm{pH}$ 7.0), or on LB agar (Carl Roth, Karlsruhe, Deutschland). Plasmids were selected by adding carbenicillin to the 
Table 1 Bacterial strains and plasmids used in this study

\begin{tabular}{|c|c|c|}
\hline Strain or plasmid & Relevant characteristics & Source or reference \\
\hline \multicolumn{3}{|l|}{ Escherichia coli } \\
\hline TOP10 & $\begin{array}{l}\text { mcrA, } \triangle(\text { mrr-hsdRMS-mcrBC), Phi80lacZ(del)M15, } \triangle \text { lacX74, deoR, recA1, araD139, } \triangle \text { (ara- } \\
\text { leu)7697, galU, galK, rpsL(SmR), endA1, nupG, strain used for general cloning procedures }\end{array}$ & Invitrogen \\
\hline C43(DE3) & F- ompT gal dcm hsdSB(rB-mB-)(DE3), strain used for protein expression & Miroux and Walker (1996) \\
\hline \multicolumn{3}{|l|}{ Plasmids } \\
\hline pSenSox & $\begin{array}{l}\text { Amp }{ }^{R} ; \text { pBtac-Lbadh derivative containing the soxRS-based NADPH biosensor and the } \\
\text { Lbadh }^{\text {WT }} \text { gene under transcriptional control of the tac promoter }\end{array}$ & Siedler et al. (2014) \\
\hline pSenNeg & $\begin{array}{l}\text { Amp } p^{R} ; \text { pSenSox derivative with an incomplete } L b a d h^{W T} \text { gene preventing synthesis of an } \\
\text { active } L b A d h^{W T}\end{array}$ & Siedler et al. (2014) \\
\hline pSenSox-Lbadh ${ }^{\mathrm{K} 71 \mathrm{E}}$ & $\mathrm{Amp}^{\mathrm{R}} ;$ pSenSox derivative with the $L$ badh $h^{\mathrm{K} 71 \mathrm{E}}$ gene under control of the tac-promoter & This study \\
\hline pASK-IBA5plus-LbadhWT & $\begin{array}{l}\text { Amp }{ }^{R} ; \text { pASK-IBA5plus derivative for production of } L b A d h^{W T} \text { with N-terminal Strep-tag II } \\
\text { under control of the tet-promoter/operator }\end{array}$ & $\begin{array}{l}\text { Prof. W. Kroutil, Department } \\
\text { of Chemistry, University of } \\
\text { Graz, Austria }\end{array}$ \\
\hline pASK-IBA5plus-Lbadh ${ }^{\mathrm{K} 71 \mathrm{E}}$ & $\begin{array}{l}\text { Amp }{ }^{\mathrm{R}} ; \mathrm{pASK} \text {-IBA5plus derivative carrying the gene construct for the purification of the } \\
\text { mutant } \angle b A d h^{\mathrm{K} 71 \mathrm{E}} \text { protein with an N-terminal Strep-Tactin affinity tag (Strep-tag II) } \\
\text { under transcriptional control of the tet-promoter/operator }\end{array}$ & This study \\
\hline
\end{tabular}

medium to a final concentration of $100 \mu \mathrm{g} \mathrm{mL} \mathrm{L}^{-1} \cdot \mathrm{BD}^{\mathrm{TM}}$ FACSFlow Sheath Fluid for flow cytometry applications was purchased from BD Biosciences (Franklin Lakes, USA).

\section{Recombinant DNA work and library construction}

Standard methods such as PCR were carried out according to established protocols (Sambrook and Russell 2001). Oligonucleotides were synthesized by Eurofins Genomics (Ebersberg, Germany) and are listed in Table 2. All plasmids were sequenced by Eurofins Genomics (Ebersberg, Germany). For random mutagenesis of the Lbadh ${ }^{\mathrm{WT}}$ gene, error-prone PCR was performed using the oligonucleotide pair pSenSox-Lbadh-fw and pSenSox-Lbadh-rv, the plasmid pSenSox as template, and the GeneMorph II Random Mutagenesis Kit (Agilent Technologies, Santa Clara CA, USA). The resulting mutated $L b a d h$ fragments were cloned by Gibson assembly (Gibson et al. 2009) into a pSenSox fragment obtained by restriction with EcoRI and HindIII to remove the $L b a d h^{\mathrm{WT}}$ gene. The Gibson assembly mixture representing the $L b a d h^{\mathrm{Library}}$ was used to transform electrocompetent cells of $E$. coli TOP10. The resulting library was composed of about $1.4 \times 10^{6}$ individual clones and was used for preparation of glycerol stocks.

The plasmid pASK-IBA5plus-Lbadh ${ }^{\mathrm{K} 71 \mathrm{E}}$ was generated by site-directed mutagenesis with pASK-IBA5plus-Lbadh ${ }^{\mathrm{WT}}$ as template, the oligonucleotide pair Lbadh-mutagenesis-A412G-fw and Lbadh-mutagenesis-A412G-rv, and the PfuUltra II Hotstart PCR Master Mix (Agilent Technologies, Santa Clara CA, USA). The plasmid pSenSox-Lbadh ${ }^{\mathrm{K} 71 \mathrm{E}}$ was obtained by amplifying the $L b a d h^{\mathrm{K} 71 \mathrm{E}}$ gene with the oligonucleotides pSenSox- $L b a d h^{-} \mathrm{fw}$ and pSenSox-Lbadh${ }^{-} \mathrm{rv}$ and

Table 2 Oligonucleotides used in this study

\begin{tabular}{|c|c|}
\hline Oligonucleotide & Sequence $\left(5^{\prime} \rightarrow 3^{\prime}\right)$ and properties \\
\hline pSenSox-Lbadh-fw & CAATTTCACACAGGAAACAGGCGGCCGCATGTCTAACCGTTTGGATG \\
\hline pSenSox-Lbadh ${ }^{-} r v$ & СTCTCATCCGCCAAAACAGAGAATTCCTATTGAGCAGTGTAGCC \\
\hline pSenSox-Lbadh Library sequencing fw & TAATCATCGGCTCGTATAATGTGTG \\
\hline pSenSox-Lbadh Library sequencing rv & GCTTCTGCGTTCTGATTTAATCTG \\
\hline Lbadh-mutagenesis A412G fw & GATGAAGATGGTTGGACCGAACTGTTTGATGCAACC \\
\hline Lbadh-mutagenesis A412G rv & GGTTGCATCAAACAGTTCGGTCCAACCATCTTCATC \\
\hline pASK-IBA5plus-Lbadh ${ }^{\mathrm{K} 71 \mathrm{E}}$ sequencing fw & GAAATAATTTTGTTTAACTTTAAGAAGG \\
\hline pASK-IBA5plus-Lbadh ${ }^{\mathrm{K} 71 \mathrm{E}}$ sequencing $r v$ & CCATTTTTCACTTCACAGGTCAAGC \\
\hline
\end{tabular}

Overlapping regions required for Gibson assembly in oligonucleotides used for cloning of the Lbadh ${ }^{\text {Library }}$ genes into pSenSox cut with EcoRl and Hindlll are shown in bold 
pASK-IBA5plus-Lbadh ${ }^{\mathrm{K} 71 \mathrm{E}}$ as template and cloning of the PCR product into plasmid pSenSox cut with HindIII and EcoRI at the former position of the Lbadh ${ }^{\mathrm{WT}}$ gene.

\section{Fluorescence-activated cell sorting (FACS)}

Flow cytometric analysis and cell sorting were performed with a FACS ARIA II high-speed cell sorter (BD Biosciences, Franklin Lakes, NJ, USA) and the BD FACS$\operatorname{Diva}^{\mathrm{TM}}$ software 6.1.3.

eYFP fluorescence of single cells was measured by using an excitation wavelength of $488 \mathrm{~nm}$ emitted by a blue solid-state laser and an emission wavelength of $533 \pm 30 \mathrm{~nm}$ at a sample pressure of $70 \mathrm{psi}$. A threshold was set to exclude non-bacterial particles on the basis of forward scatter (FSC) area versus side scatter (SSC) area. The flow rate was set to analyze $2000-4000$ cells per second. For graphical representation of the obtained data as dot plots or histograms, the software FlowJo (FlowJo, LLC, Ashland, OR, USA) was used.

The strategy used to isolate cells containing $L b A D H$ variants with improved activity for reduction of 2,5-hexanedione included three enrichments steps with positive selection followed by one negative selection step and another positive selection step. A 1-mL culture of E. coli TOP10/pSenSox-Lbadh $h^{\text {Library }}$ in 2xTY medium containing $100 \mu \mathrm{g} \mathrm{mL}^{-1}$ carbenicillin with an initial optical density at $600 \mathrm{~nm}\left(\mathrm{OD}_{600}\right)$ of 0.2 was incubated for $4 \mathrm{~h}$ at $37{ }^{\circ} \mathrm{C}$ and $900 \mathrm{rpm}$ in a 48 -well non-transparent Flowerplate (m2p-labs GmbH, Baesweiler, Deutschland). Then the cells were harvested by centrifugation and resuspended in fresh 2xTY medium supplemented with $100 \mu \mathrm{g} \mathrm{mL} \mathrm{g}^{-1}$ carbenicillin to a final $\mathrm{OD}_{600}$ of 3 or higher. $800 \mu \mathrm{L}$ of these suspensions were transferred into another 48-well Flowerplate and after addition of $100 \mu \mathrm{L}$ 2,5-hexanedione to a final concentration of $70 \mathrm{mM}$, the plate was incubated for $2.5 \mathrm{~h}$ at $37{ }^{\circ} \mathrm{C}$ and $900 \mathrm{rpm}$ for $\mathrm{NADPH}$-dependent reduction of 2,5-hexanedione to $(2 R, 5 R)$-hexanediol and concomitant NADPH-dependent expression of eyfp. Then the cultures were diluted 50 -fold in sterile-filtered BD $^{\mathrm{TM}}$ FACSFlow Sheath Fluid (BD, Franklin Lakes, USA) and subjected to FACS.

The sorting gate was set to include the $1 \%$ most fluorescent cells. $3 \times 10^{4}$ of these cells were sorted into fresh 2xTY medium containing $100 \mu \mathrm{g} \mathrm{mL} \mathrm{m}^{-1}$ carbenicillin. After overnight cultivation, a new 1-mL culture was inoculated, incubated for $4 \mathrm{~h}$ and then used again for biotransformation of 2,5-hexanedione. Afterwards, the cells were again screened by FACS, $3 \times 10^{4}$ of the most fluorescent cells were isolated and the positive selection repeated for a third time. After culturing the cells of the third enrichment step, they were subjected to a mock biotransformation in which 2,5-hexanedione was omitted and then analyzed by FACS. In this case, the non-fluorescent cells were sorted in order to remove cells showing high fluorescence independent of $\mathrm{LbADH}$-catalyzed 2,5-hexanedione reduction. For setting the sorting gate, cells of E. coli TOP10/pSenNeg were used, which lack an active $L b A D H .1 \times 10^{5}$ library cells within the negative sorting gate were collected in fresh $2 \times T Y$ medium with $100 \mu \mathrm{g} \mathrm{mL}^{-1}$ carbenicillin. After overnight cultivation, a fourth round of positive selection was performed using cells after $2.5 \mathrm{~h}$ biotransformation of 2,5-hexanedione. Cells of $E$. coli TOP10/pSenSox with wild-type $L b A D H$ were used as reference and 240 library cells showing a higher fluorescence than the reference were spotted on LB agar plates with $100 \mu \mathrm{g} \mathrm{mL}^{-1}$ carbenicillin.

83 out of the 240 spotted cells formed colonies after overnight incubation at $37{ }^{\circ} \mathrm{C}$ and were subsequently analyzed in a BioLector microcultivation system (m2plaps, Baesweiler, Germany) by following eYFP fluorescence and growth as described below. 65 clones showed the same fluorescence pattern with a higher fluorescence compared to the reference strain E. coli TOP10/pSenSox expressing the wild-type $L b a d h^{\mathrm{WT}}$ gene in the presence of the substrate 2,5-hexanedione. The plasmids of four of these strains were isolated and sequenced. All four clones carried a single $\mathrm{G} \rightarrow \mathrm{A}$ transition in the Lbadh gene resulting in the amino acid exchange K71E.

\section{Biotransformation and monitoring of the NADPH biosensor response}

The fluorescence intensity of the NADPH biosensor signal was measured during the whole-cell biotransformation of the substrate 2,5-hexanedione. To test the difference in the fluorescence intensity, pre-cultures of the cultures obtained after FACS screening and the E. coli TOP10/pSenSox culture as positive control were incubated overnight at $37{ }^{\circ} \mathrm{C}$ and $130 \mathrm{rpm}$ in $5 \mathrm{~mL} 2 \mathrm{xTY}$ medium containing $100 \mu \mathrm{g} \mathrm{mL} \mathrm{m}^{-1}$ carbenicillin. The precultures were used to inoculate main cultures in 2 xTY medium with $100 \mu \mathrm{g} \mathrm{mL} \mathrm{g}^{-1}$ carbenicillin to an $\mathrm{OD}_{600}$ of 0.05 , which were cultivated at $37^{\circ} \mathrm{C}$ and $130 \mathrm{rpm}$. The cells were further cultivated for $5 \mathrm{~h}$, harvested by centrifugation $\left(4^{\circ} \mathrm{C}, 4713 \mathrm{~g}, 15 \mathrm{~min}\right)$ and resuspended in $5 \mathrm{~mL}$ fresh 2xTY medium supplemented with $100 \mu \mathrm{g} \mathrm{mL} \mathrm{m}^{-1}$ carbenicillin to a final $\mathrm{OD}_{600}$ of $5.800 \mu \mathrm{L}$ of these suspensions were transferred into a 48-well Flowerplate (m2p-laps, Baesweiler, Germany). To start the biotransformation of the substrates, $100 \mu \mathrm{L}$ of the substrate 2,5-hexanedione dissolved in $\mathrm{ddH}_{2} \mathrm{O}$ was added to the cultures to a final concentration of $70 \mathrm{mM}$. $100 \mu \mathrm{L}$ $\mathrm{dd}_{2} \mathrm{O}$ were added to the cultures instead of the substrates as negative controls. After the desired additions, the Flowerplates were incubated in a BioLector microcultivation system at $30{ }^{\circ} \mathrm{C}$ and $1200 \mathrm{rpm}$ (shaking diameter 
$3 \mathrm{~mm}$ ) and eYFP fluorescence (excitation wavelength $485 \mathrm{~nm}$, emission wavelength of $520 \mathrm{~nm}$ ) and cell density (as backscattered light at $620 \mathrm{~nm}$ ) were monitored online (Kensy et al. 2009).

\section{$\angle b A D H$ overproduction and purification}

For enzyme production, E. coli C43(DE3) carrying pASKIBA5plus- $L b a d h^{\mathrm{WT}}$ or pASK-IBA5plus- $L b a d h^{\mathrm{K} 71 \mathrm{E}}$ was cultivated in TB medium supplemented with $1 \mathrm{mM}$ $\mathrm{MgCl}_{2}$ and $100 \mu \mathrm{g} \mathrm{mL} \mathrm{m}^{-1}$ carbenicillin. Pre-cultures were used to inoculate $1 \mathrm{~L}$ main cultures in a $5 \mathrm{~L}$ shaking flask to a starting $\mathrm{OD}_{600}$ of 0.1. The main cultures were shaken at $37^{\circ} \mathrm{C}$ and $130 \mathrm{rpm}$ until an $\mathrm{OD}_{600}$ of 0.6 was reached. Then $L b A D H$ overproduction was induced with $0.2 \mathrm{mg} \mathrm{L}^{-1}$ anhydrotetracycline and the cultures were then incubated for $20 \mathrm{~h}$ at $20^{\circ} \mathrm{C}$ and $130 \mathrm{rpm}$. Subsequently, the cells were harvested by centrifugation $\left(4{ }^{\circ} \mathrm{C}, 4713 g, 30 \mathrm{~min}\right)$, resuspended in $5 \mathrm{~mL}$ lysis buffer (100 mM Tris/ $\mathrm{HCl}$ buffer at $\mathrm{pH} 7.2$ with $1 \mathrm{mM} \mathrm{MgCl}_{2}$, $1 \mu \mathrm{g} \mathrm{mL}^{-1}$ DNAse and protease inhibitor (cOmplete ${ }^{\mathrm{TM}}$ ULTRA Tablets, Mini, EDTA-free, EASYpack Protease Inhibitor Cocktail, Roche, Basel, Switzerland), and incubated for $20 \mathrm{~min}$ on ice. For cell disruption, the cell suspension was passed three times through a French pressure cell at $110 \mathrm{MPa}$. To sediment intact cells and cell debris, the extract was centrifuged for $60 \mathrm{~min}$ at $10,000 \mathrm{~g}$ and $4{ }^{\circ} \mathrm{C}$. The resulting supernatant was filtered through a $0.22 \mu \mathrm{m}$ filter (Millex-GP, polyethersulfon, Merck Millipore, Tullagreen, Ireland) and used for a two-step purification process with an $\ddot{A k t a}{ }^{\mathrm{TM}}$ Pure chromatography system (GE Healthcare Bio-Sciences, Uppsala, Sweden). First, $\mathrm{LbADH}$ was isolated by affinity chromatography using a $1 \mathrm{~mL}$ Strep-Trap ${ }^{\mathrm{TM}} \mathrm{HP}$ column (GE Healthcare Bio-Sciences, Uppsala, Sweden) equilibrated with $100 \mathrm{mM}$ Tris/ $\mathrm{HCl}$ buffer $\mathrm{pH} 7.2$ containing $1 \mathrm{mM} \mathrm{MgCl}$ according to the protocol provided by the manufacturer. For elution of specifically bound proteins, equilibration buffer supplemented with $2.5 \mathrm{mM}$ desthiobiotin was used. For the second purification step, size exclusion chromatography was performed using a Super$\operatorname{dex}^{\text {TM }} 200$ increase 10/300 GL column (GE Healthcare Bio-Sciences, Uppsala, Sweden) equilibrated with buffer A $(50 \mathrm{mM}$ triethanolamine hydrochloride (TEA) containing $1 \mathrm{mM} \mathrm{MgCl}_{2}$ and adjusted to $\mathrm{pH} 7.0$ with $1 \mathrm{M}$ $\mathrm{NaOH}) . L b \mathrm{ADH}^{\mathrm{WT}}$ and $L b \mathrm{ADH}^{\mathrm{K} 71 \mathrm{E}}$ were eluted with

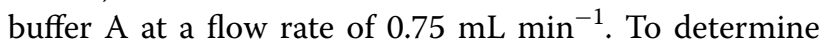
the molecular mass of the eluted proteins, a calibration curve was established by performing size exclusion chromatography under the same conditions with proteins of known size, namely carbonic anhydrase $(29 \mathrm{kDa})$, bovine serum albumin $(66 \mathrm{kDa})$, alcohol dehydrogenase $(150 \mathrm{kDa})$ and $\beta$-amylase $(200 \mathrm{kDa})$. Protein concentrations were determined using a bicinchoninic acid assay
(Interchim, Montluçon, France). $1 \mu \mathrm{g}$ protein of the elution fraction obtained after affinity purification and $1 \mu \mathrm{g}$ protein of the elution fraction obtained after size exclusion chromatography were analyzed by sodium dodecyl sulfate-polyacrylamide gel electrophoresis (SDS-PAGE) using a Mini-PROTEAN ${ }^{\circledR}$ TGX $^{\mathrm{TM}}$ Any $\mathrm{kD}^{\mathrm{TM}}$ gel (Bio-Rad Laboratories, Hercules CA, USA).

\section{Dynamic light scattering (DLS) and thermal shift assay}

DLS analysis was carried out on the concentrated enzyme (0.6-1.2 $\mathrm{mg} \mathrm{mL}^{-1}$ ) using a DynaPro Nanostar (Wyatt technology, Santa Barbara, CA, USA). The hydrodynamic radius was measured, and the molecular weight was calculated by DYNAMICS V6.

For the thermal shift assay, $20 \mu \mathrm{L}$ of the protein solution $\left(0.6-1.2 \mathrm{mg} \mathrm{mL}^{-1}\right)$ was mixed with $5 \mu \mathrm{L} 100 \times \mathrm{SYPRO}$ Orange in a plate suitable for RT-PCR and sealed with a transparent cover. In a CFX96 RT-PCR machine (BioRad, Hercules, CA, USA), a melt curve program was set up where the temperature ramps from 20 to $95{ }^{\circ} \mathrm{C}$ with $0.5{ }^{\circ} \mathrm{C}$ increments after a $10 \mathrm{~s}$ delay. At each interval, a fluorescence measurement using the SYBR Green filter set was performed. The Bio-Rad software was used to determine the first derivative of the fluorescence signal and the temperature. The maximum of this curve was taken as the apparent $T_{m}$ of the protein.

\section{Activity of $\angle b A D H^{W T}$ and $\angle b A D H^{\mathrm{K} 71 \mathrm{E}}$ with various substrates}

The kinetic properties of purified $L b \mathrm{ADH}^{\mathrm{WT}}$ and $L b \mathrm{AD}$ $\mathrm{H}^{\mathrm{K} 71 \mathrm{E}}$ were analyzed using an assay in which the oxidation of NADPH was followed at $340 \mathrm{~nm}$ using a JASCO V560 UV/VIS spectrophotometer (JASCO, Gross-Umstadt, Germany) equipped with a water bath-heated cell holder set at $30^{\circ} \mathrm{C}$. The assay was performed in disposable semimicro cuvettes made of polystyrene (Sarstedt, Nürnbrecht, Germany) containing $1 \mathrm{~mL}$ assay buffer composed of $50 \mathrm{mM}$ TEA pH 7.0, $1 \mathrm{mM} \mathrm{MgCl}, 0.3 \mathrm{mM} \mathrm{NADPH}$, $0.7 \mu \mathrm{g}$ purified $L b \mathrm{ADH}^{\mathrm{WT}}$ or $L b \mathrm{ADH}^{\mathrm{K} 71 \mathrm{E}}$, and different concentrations of the substrate. For 2,5-hexanedione, concentrations from $1 \mathrm{mM}$ to $20 \mathrm{mM}$ were used, for methyl acetoacetate $0.195 \mathrm{mM}$ to $12.5 \mathrm{mM}$. To determine the $K_{M}$ value for NADPH, $20 \mathrm{mM}$ 2,5-hexanedione and $\mathrm{NADHPH}$ concentrations from $0.003 \mathrm{mM}$ to $0.3 \mathrm{mM}$ were used. The activity for acetophenone was determined at $5 \mathrm{mM}$, the activities for 2-acetylpyridine, 2-hexanone, and 4-hydroxy-2-butanone were determined at $10 \mathrm{mM}$. The progress of NADPH consumption was measured continuously for $1 \mathrm{~min}$ and used to calculate the corresponding enzyme activity using a molar extinction coefficient for NADPH at $340 \mathrm{~nm}$ of $6.22 \mathrm{mM}^{-1} \mathrm{~cm}^{-1}$. The data were used to create Michaelis-Menten and LineweaverBurk plots. $\mathrm{K}_{\mathrm{M}}$ and $\mathrm{V}_{\max }$ values were determined by 
nonlinear regression of the Michaelis-Menten equation using the software GraphPad Prism 7 (GraphPad Software, La Jolla California USA).

\section{GenBank/EMBL accession numbers}

The GenBank/EMBL accession number for the nucleotide sequence of the Lbadh gene is AJ544275. The GenBank/EMBL accession number for the amino acid sequence of the $L b A D H$ protein is CAD66648.

\section{Results}

\section{Construction of an LbADH library and FACS screening}

We aimed at finding $L b A D H$ variants with improved catalytic properties for the reduction of 2,5-hexandione to $(2 R, 5 R)$-hexanediol by FACS-based HT-screening using the NADPH biosensor pSenSox. For this purpose, a library of $L b a d h$ variants was generated by error-prone PCR and used to replace the $L b a d h^{\mathrm{WT}}$ gene of pSenSox. The resulting library pSenSox- $L b a d h^{\text {Library, }}$ present in E. coli TOP10, had an estimated size of $1.4 \times 10^{6}$ clones. A culture expressing the $L$ badh ${ }^{\text {Library }}$ was used for the biotransformation of 2,5-hexanedione by incubation for $2.5 \mathrm{~h}$ in $2 \mathrm{xTY}$ medium supplemented with $70 \mathrm{mM}$ of the diketone. Preliminary studies had revealed that cells expressing $L b a d h^{\mathrm{WT}}$ showed maximal specific fluorescence during the biotransformation of 2,5-hexanedione after 2 to $3 \mathrm{~h}$.

After biotransformation, the library cells were diluted and subjected to FACS (Fig. 1) as described in detail in the methods section. The entire screening process comprised three positive selection steps for cells showing high fluorescence after biotransformation of 2,5-hexanedione followed by a negative selection step. In the latter, cells showing high fluorescence independent of 2,5-hexanedione were excluded by collecting only those cells in the library that showed the same fluorescence as $E$. coli TOP10/pSenNeg cells lacking an active $L b A D H$. After propagation, these cells were subjected to a fourth round of positive selection. $2.5 \times 10^{5}$ cells of the library were analyzed and 240 cells showing a higher fluorescence than the reference strain E. coli TOP10/pSenSox containing wild-type $L b A D H$ were spotted on agar plates and incubated overnight at $37{ }^{\circ} \mathrm{C} .83$ cells (35\%) formed colonies and were further analyzed.

\section{Initial characterization of isolated clones in the BioLector}

To confirm the increased fluorescence of the 83 isolated clones, they were cultivated in a BioLector system in 2 XTY medium with or without $70 \mathrm{mM} \mathrm{2,5-hexanedi-}$ one. The specific fluorescence of the cultures (the ratio of absolute fluorescence over cell density determined as
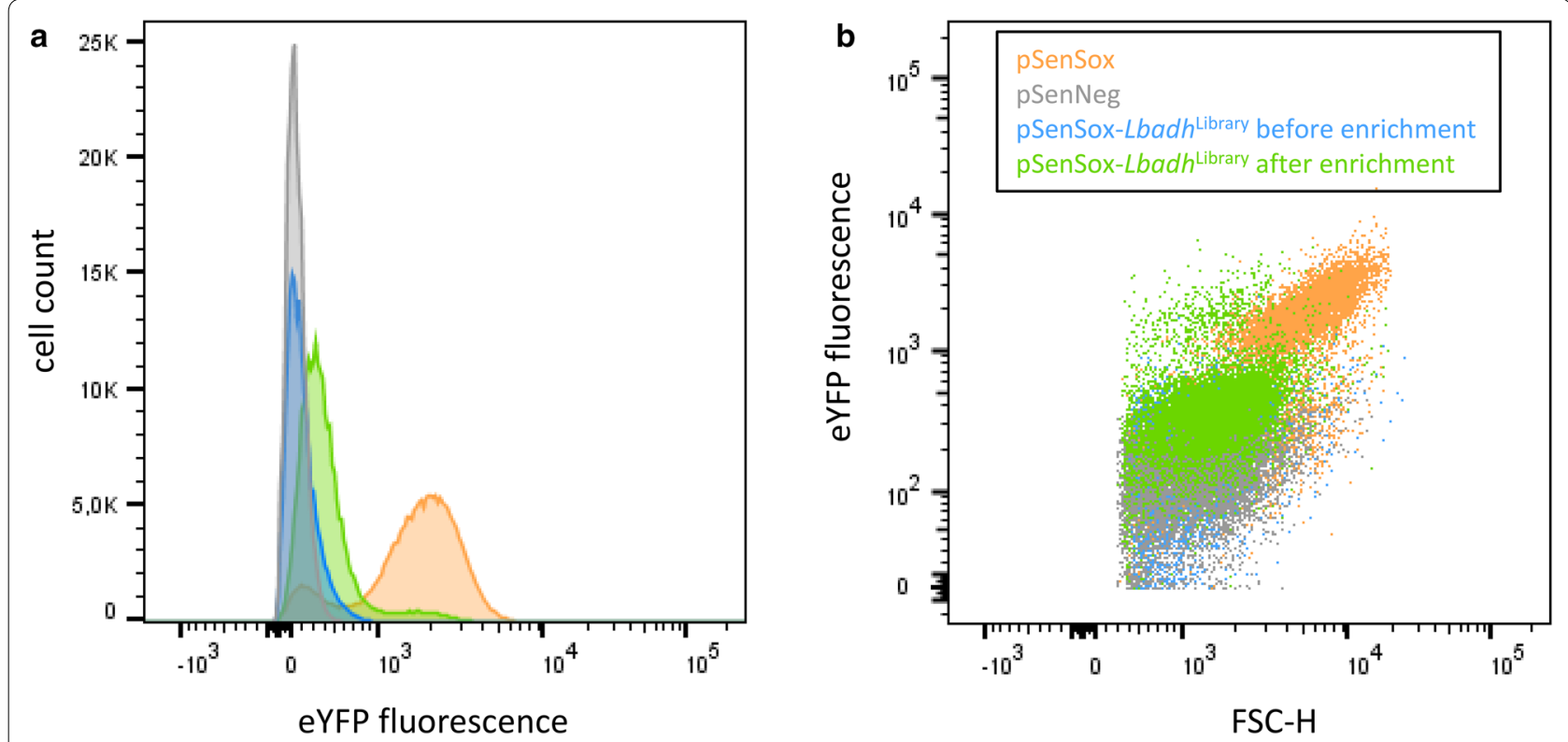

Fig. 1 FACS analysis of the LbADH mutant library. Comparison of the fluorescence distribution of the E. coliTOP10/pSenSox-Lbadh ${ }^{\text {Library }}$ culture $^{\text {L }^{2}}$ before (blue) and after three positive enrichment steps followed by one negative and another positive enrichment step (green). E. coli TOP10/ pSenSox cells (orange) were used as positive control and E. coliTOP10/pSenNeg cells (gray) as negative control. Before FACS analysis, cells of the different cultures were incubated for $2.5 \mathrm{~h}$ with the substrate 2,5 -hexanedione. Prior to sorting, $2.5 \times 10^{5}$ cells of each culture were analyzed. The plots were generated with the BD DIVA 6.1.3 software. a Histogram of the four E. coli cultures described above. $\mathbf{b}$ Dot plots of the four cultures described above displaying the eYFP fluorescence signal against the forward scatter height (FSC-H) reflecting the size of the cells 
backscatter at $620 \mathrm{~nm}$ ) was monitored online for around $24 \mathrm{~h}$. As reference, the strain expressing the wild-type Lbadh gene was used. Several of the clones showed an increased specific fluorescence in the presence of 2,5-hexanedione compared to the absence of 2,5-hexanedione and a higher specific fluorescence than the reference strain with wild-type $L b A D H$. Sequencing of the plasmids isolated from four of these clones revealed that all carried a single $\mathrm{G} \rightarrow \mathrm{A}$ transition in the Lbadh gene resulting in the amino acid exchange K71E. The finding that all four clones contained the same mutation is probably due the applied selection procedure involving four positive and one negative selection step.

To confirm that this mutation, rather than secondary mutations in the pSenSox plasmid or in the genomic DNA, was responsible for the increased fluorescence during the biotransformation of 2,5-hexanedione, the Lbadh $^{\mathrm{K} 71 \mathrm{E}}$ gene was amplified by PCR, used to replace the wild-type Lbadh gene in plasmid pSenSox, and transferred into $E$. coli TOP10. Cultivation of the recombinant strain carrying pSenSox-Lbadh ${ }^{\mathrm{K} 71 \mathrm{E}}$ in a BioLector system confirmed that it shows a higher specific fluorescence in the presence of 2,5-hexanedione than in the absence, and higher fluorescence than E. coli TOP10/ pSenSox with wild-type $L b A D H$ (data not shown). This result supported the assumption that the K71E mutation in $\mathrm{LbADH}$ was responsible for the increased fluorescence and leads to improved properties for 2,5-hexanedione reduction.

\section{Purification and biochemical characterization of $L b A D H^{W T}$ and $L b A D H^{K 71 E}$}

To characterize and compare the $L b \mathrm{ADH}^{\mathrm{K} 71 \mathrm{E}}$ variant with the $L b A D H^{\mathrm{WT}}$, both enzymes containing an $\mathrm{N}$-terminal StrepTag-II were overproduced in E. coli C43(DE3) using the expression plasmids pASK-IBA5plus-Lbadh ${ }^{\mathrm{WT}}$ and pASK-IBA5plus-Lbadh ${ }^{\mathrm{K} 71 \mathrm{E}}$ and purified by StrepTactin Sepharose affinity chromatography followed by size-exclusion chromatography (Fig. 2). The two proteins showed an identical elution profile in the affinity chromatography (Fig. 2a), but in the size-exclusion chromatography, the $L b \mathrm{ADH}^{\mathrm{K} 71 \mathrm{E}}$ eluted slightly before $L b \mathrm{ADH}^{\mathrm{WT}}$ (Fig. 2b). Consequently, the apparent mass calculated from a calibration curve (Fig. 2c) derived from standard proteins was somewhat larger for $L b \mathrm{ADH}^{\mathrm{K} 71 \mathrm{E}}\left(113 \mathrm{kDa}\right.$ ) than for $L b \mathrm{ADH}^{\mathrm{WT}}$ (95 kDa). The elution volume difference of $\sim 0.39 \mathrm{~mL}$ between $L b \mathrm{ADH}^{\mathrm{WT}}$ and $L b \mathrm{ADH}^{\mathrm{K} 71 \mathrm{E}}$ was consistent for three independent protein preparations with varying sample order and indicated a structural change triggered by the K71E exchange. The apparent native masses of $95 \mathrm{kDa}$ and $113 \mathrm{kDa}$ are in agreement with the known tetrameric structure of $\mathrm{LbADH}$ (calculated mass of monomer including StrepTag-II is $28.2 \mathrm{kDa}$ ). A structural change caused by the K71E exchange became also apparent after analysis of the purified proteins by SDSPAGE: LbADH ${ }^{\mathrm{K} 71 \mathrm{E}}$ shows a slightly higher apparent mass than $L b \mathrm{ADH}^{\mathrm{WT}}$ (Fig. 2d).

To further analyze the structural difference of the two LbADH variants, dynamic light scattering (DLS) was performed with the purified enzymes. The results showed a monodisperse sample with a slight amount of aggregates that were more prevalent for the wildtype ADH than for the K71E variant. The radius and calculated mass (based on a globular shape) were slightly smaller for $\operatorname{LbADH}^{\mathrm{K} 71 \mathrm{E}}(\mathrm{r}=3.75 \pm 0.07 \mathrm{~nm}$; $72.5 \pm 3.5 \mathrm{kDa})$ than for $L b \mathrm{ADH}^{\mathrm{WT}}(\mathrm{r}=3.85 \pm 0.07 \mathrm{~nm}$; $78.5 \pm 4.9 \mathrm{kDa})$, but the difference was too small to be significant.

To test whether the K71E exchange has an influence on $L b \mathrm{ADH}$ stability, the apparent melting point of the two protein variants was determined using a thermal shift assay with the dye SYPRO orange. $L b \mathrm{ADH}^{\mathrm{K} 71 \mathrm{E}}$ appeared to be slightly more stable with a melting point of $52.8 \pm 0.3{ }^{\circ} \mathrm{C}$ in comparison to $L b A D H^{\mathrm{WT}}$ with a melting point of $51.5 \pm 0.0{ }^{\circ} \mathrm{C}$ (data of three technical replicates).

The pure enzymes were used for kinetic analysis using a spectrophotometric assay measuring NADPH consumption at $340 \mathrm{~nm}$ (see Methods section for details). In initial studies, the affinity and activity for the substrate 2,5-hexanedione were determined using Michaelis-Menten and Lineweaver-Burk plots (Fig. 3, Table 3). The $\mathrm{K}_{\mathrm{M}}$ value determined for $L b \mathrm{ADH}^{\mathrm{K} 71 \mathrm{E}}$ $(4.3 \pm 0.5 \mathrm{mM})$ was $16 \%$ lower than the one determined for $L b \mathrm{ADH}^{\mathrm{WT}}(5.1 \pm 0.6 \mathrm{mM})$. The maximal activity calculated for $L b \mathrm{ADH}^{\mathrm{K} 71 \mathrm{E}}\left(173.3 \pm 11.1 \mu \mathrm{mol} \mathrm{min}^{-1} \mathrm{mg}^{-1}\right)$ was $17 \%$ higher than that of $L b A D H^{\mathrm{WT}}$ $\left(148.5 \pm 12.3 \mu \mathrm{mol} \mathrm{min}^{-1} \mathrm{mg}^{-1}\right)$. Consequently, LbAD$\mathrm{H}^{\mathrm{K} 71 \mathrm{E}}$ is more active than $L b \mathrm{ADH}^{\mathrm{WT}}$ regarding the NADPH-depedent reduction of 2,5-hexanedione and has a higher affinity for this substrate. No activity was found when NADPH was replaced by NADH. To test whether the improved kinetic properties of $L b A D$ $\mathrm{H}^{\mathrm{K} 71 \mathrm{E}}$ are specific for 2,5-hexanedione, we determined the $K_{M}$ and $V_{\max }$ values for methyl acetoacetate. Also for this substrate, $L b A D H^{\mathrm{K} 71 \mathrm{E}}$ showed a better affinity and a higher maximal activity than $L b \mathrm{ADH}^{\mathrm{WT}}$ (Fig. 3c, d, Table 3). In a further set of experiments, the activity of the two enzymes for four other substrates was compared at a single concentration. As summarized in Table $4, L b \mathrm{ADH}^{\mathrm{K} 71 \mathrm{E}}$ showed $21-39 \%$ higher activity for 2-acetylpyridine, 2-hexanone, acetophenone, and 4-hydroxy-2-butanone, suggesting that the positive effect of the K71E exchange on $\mathrm{LbADH}$ activity was independent of the substrate. 


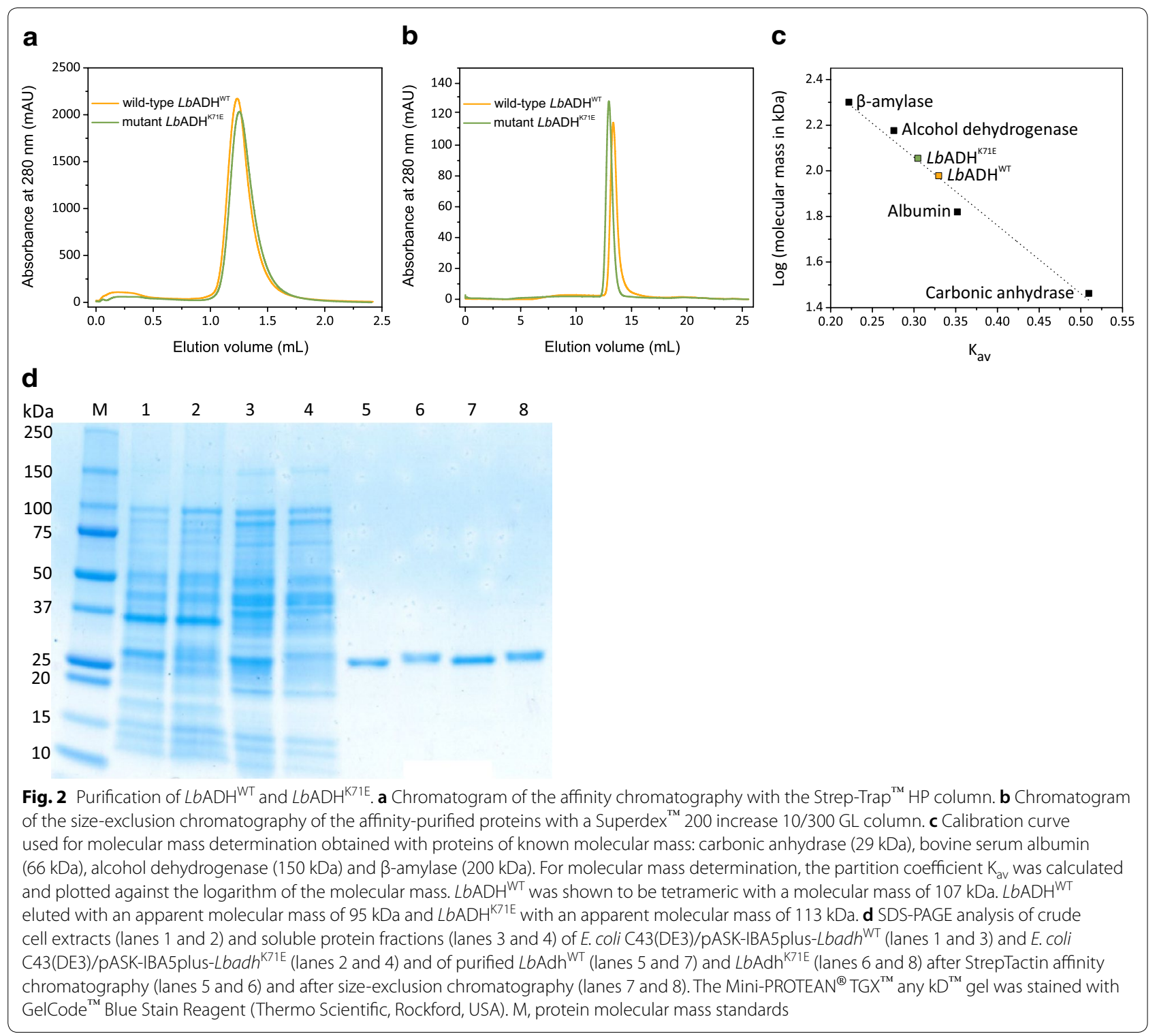

\section{Discussion}

A FACS-based HT approach to identify optimized variants of $L b A D H$ for NADPH-dependent reduction of 2,5-hexanedione resulted in the isolation of $L b \mathrm{ADH}^{\mathrm{K} 71 \mathrm{E}}$. The exchange of a lysine residue to a glutamic acid residue at position 71 led to an increased activity and a better affinity for 2,5-hexanedione, but also for the substrate methyl acetoacetate. Furthermore, up to 39\% increased activities were found for the substrates 2-acetylpyridine, 2-hexanone, acetophenone, and 4-hydroxy-2-butanone. The crystal structure of the $L b \mathrm{ADH}^{\mathrm{WT}}$ homotetramer in complex with the substrate acetophenone, the cofactor NADPH and $\mathrm{Mg}^{2+}$ is available (Schlieben et al. 2005). Interestingly, position 71 is not located close to the active center at the protein core, but solvent-exposed on the protein surface (Fig. 4). According to PyMOL 2.2.0 (Schrödinger 2015), the distance of position 71 to the substrate acetophenone is around $28.0 \AA$ and to the cofactor NADPH approximately 14.1 $\AA$. The distance to the amino acids involved in catalysis, Asn113, Ser142, Tyr155, and Lys159 (Niefind et al. 2003) of the closest active site, is 19.4 $\AA, 27.4 \AA$, $27.1 \AA$ and $25.7 \AA$, respectively. The distance to the active center suggests that the amino acid at position 71 is not directly involved in substrate binding and reduction.

Apart from the position of the mutation, the nature of the amino acid exchange has to be considered. The mutation led to an exchange of a lysine residue with a 

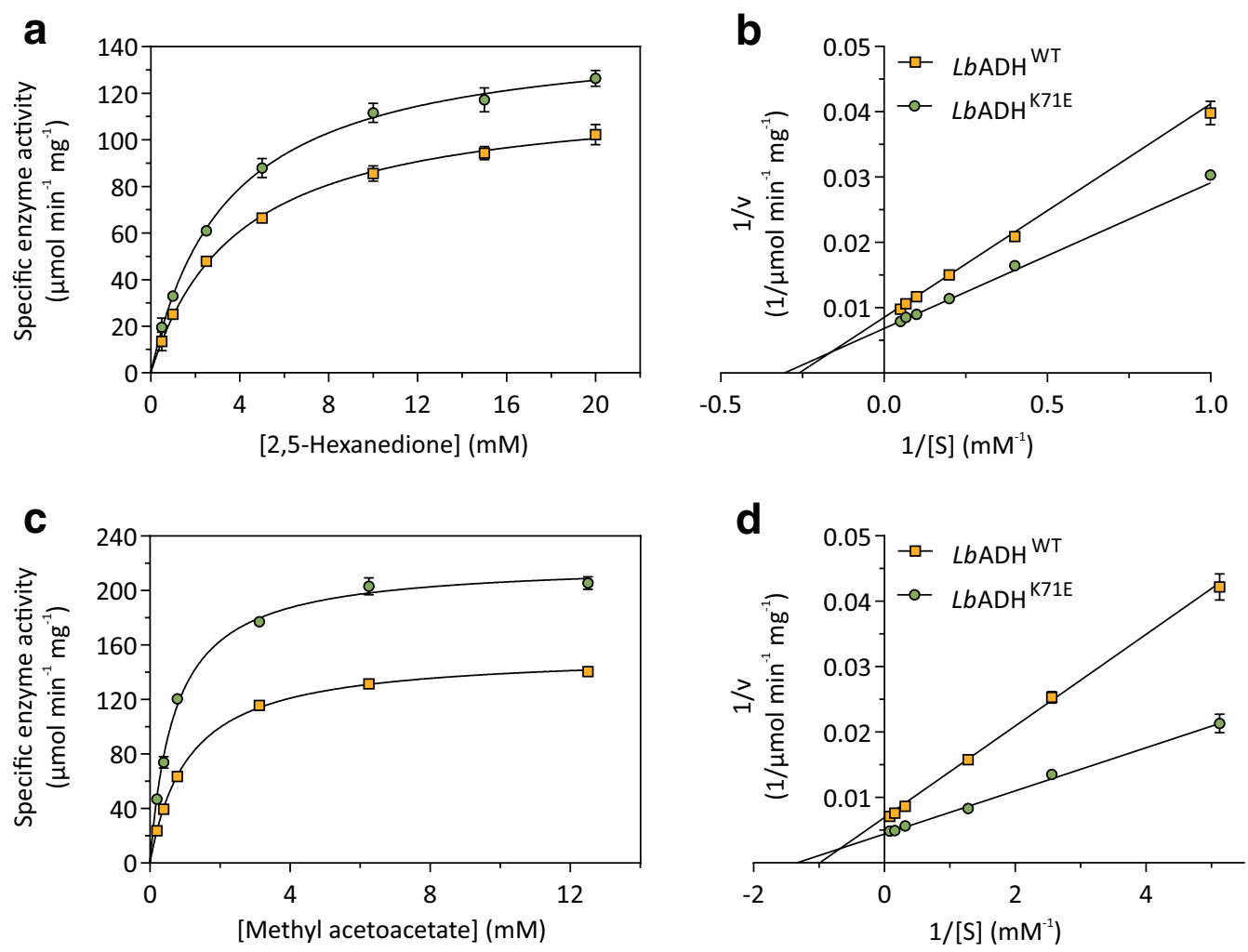

Fig. 3 Representative Michaelis-Menten plots $(\mathbf{a}, \mathbf{c})$ and Lineweaver-Burk plots $(\mathbf{b}, \mathbf{d})$ for NADPH-dependent reduction of 2,5-hexanedione to $(2 R, 5 R)$-hexandiol $(\mathbf{a}, \mathbf{b})$ and of methyl acetoacetate to $(R)$-methyl 3-hydroxybutyrate $(\mathbf{c}, \mathbf{d})$ by purified $\angle b A D H^{W T}$ and $\angle b A D H^{K 71 E}$. Data are mean values from three technical replicates of a single protein preparation

Table 3 Kinetic parameters of purifed $L b A D H^{W T}$ and $L b A D H^{K 71 E}$ for various substrates

\begin{tabular}{|c|c|c|c|c|}
\hline \multirow[t]{2}{*}{ Substrate } & \multicolumn{2}{|c|}{$\mathrm{V}_{\max }\left(\mu \mathrm{mol} \mathrm{min}^{-1} \mathrm{mg}^{-1}\right)$} & \multicolumn{2}{|l|}{$\mathrm{K}_{\mathrm{M}}(\mathrm{mM})$} \\
\hline & $L b A D H^{W T}$ & $\angle b A D H^{K 71 E}$ & $\mathrm{LbADH}^{\mathrm{WT}}$ & $\angle b A D H^{K 71 E}$ \\
\hline nedione $\mathrm{e}^{\mathrm{a}}$ & $148.5 \pm 12.3$ & $173.3 \pm 11.1$ & $5.1 \pm 0.6$ & $4.3 \pm 0.5$ \\
\hline $\begin{array}{l}\text { Methyl } \\
\text { acetoacetate }^{\text {b }}\end{array}$ & $154.2 \pm 2.2$ & $221.2 \pm 3.3$ & $1.13 \pm 0.06$ & $0.67 \pm 0.04$ \\
\hline
\end{tabular}

a Mean values and standard deviation based on three separate protein preparations with three technical replicates per preparation

b Mean values and standard deviation based on a single protein preparation and three technical replicates positively charged amino group by a glutamate residue with a negatively charged carboxyl group. The enzyme activity assays were performed at $\mathrm{pH}$ 7. The K71E exchange on the $L b$ AHD protein surface will influence its net charge and isoelectric point (pI), as these parameters depend on the content of ionizable groups and their $\mathrm{p} K_{\mathrm{a}}$ values (Shaw et al. 2001). According to a protein parameter calculator (https://web.expasy.org/protparam), the $\mathrm{K} 71 \mathrm{E}$ exchange resulted in a change of the $\mathrm{PI}$ from 5.44 for $L b \mathrm{Adh}^{\mathrm{WT}}$ to 5.17 for $L b \mathrm{Adh}^{\mathrm{K} 71 \mathrm{E}}$. SDS-PAGE also suggested that the mutation K71E changed the electrostatic

Table 4 Analysis of $\angle b A D H^{\mathrm{WT}}$ and $\angle b A D H^{\mathrm{K} 71 \mathrm{E}}$ activity for the substrates methyl acetoacetate, 2-acetylpyridine, 4-hydroxy2-butanone, acetophenone, and 2-hexanone

\begin{tabular}{|c|c|c|c|c|}
\hline Substrate & $\begin{array}{l}\text { Substrate concentration } \\
(\mathrm{mM})\end{array}$ & $\begin{array}{l}\begin{array}{l}L b A D H^{W T} \\
\left.\mathrm{mg}^{-1}\right)\end{array}\end{array}$ & $\begin{array}{l}\text { LbADH }{ }^{\mathrm{K} 71 \mathrm{E}} \text { activity } \\
\left(\mu \mathrm{mol} \min ^{-1} \mathrm{mg}^{-1}\right)\end{array}$ & $\%$ increase \\
\hline 2-Acetylpyridine & 10 & $104.1 \pm 1.7$ & $125.5 \pm 1.1$ & 21 \\
\hline 2-Hexanone & 10 & $22.8 \pm 0.7$ & $27.9 \pm 1.1$ & 22 \\
\hline acetophenone & 5 & $29.8 \pm 0.7$ & $39.5 \pm 0.7$ & 33 \\
\hline 4-Hydroxy-2-butanone & 10 & $39.5 \pm 1.3$ & $54.9 \pm 4.6$ & 39 \\
\hline
\end{tabular}

Mean values obtained from a single protein preparation and three technical replicates are shown 


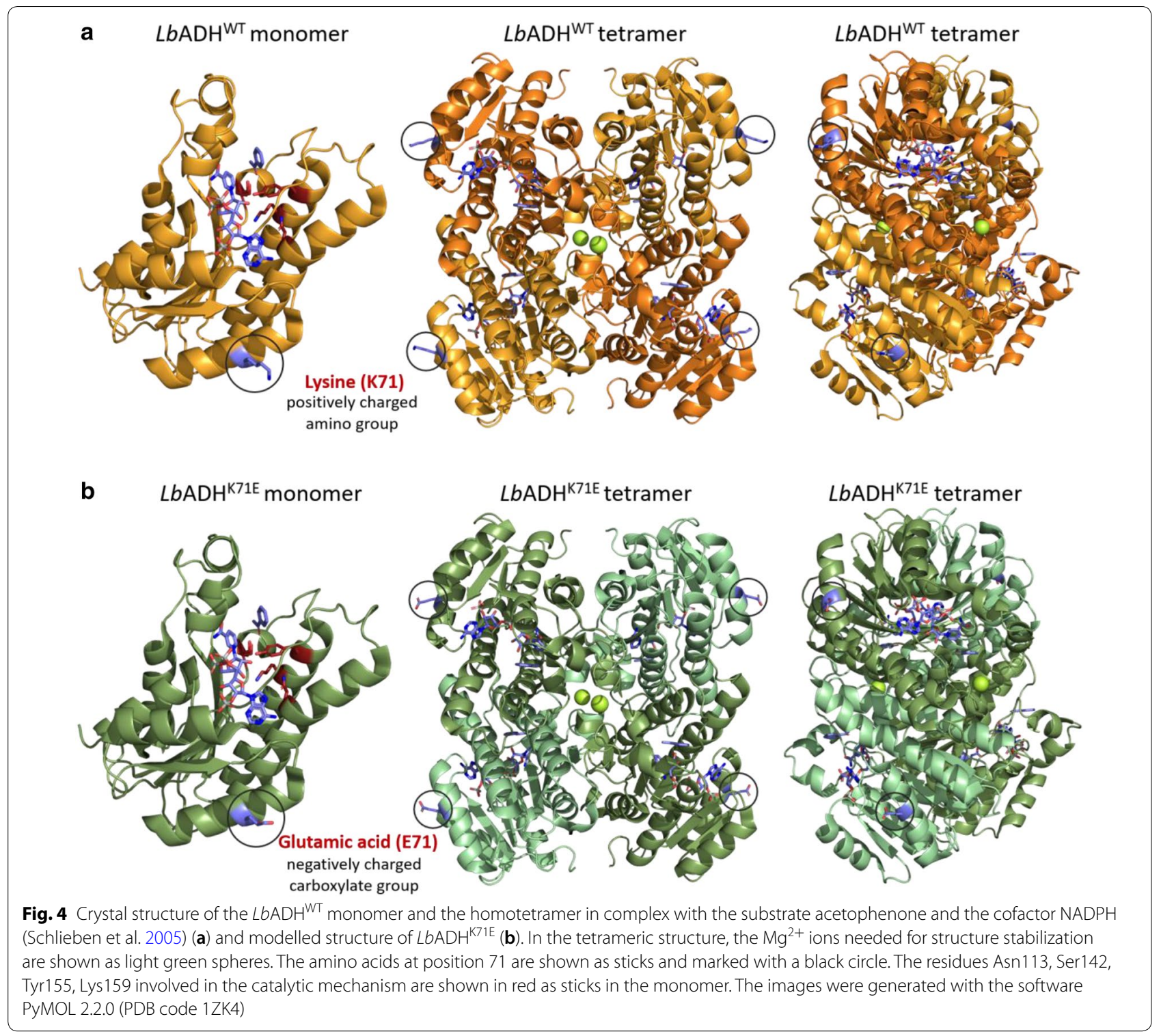

properties of the enzyme, because $L b A D H^{\mathrm{K} 71 \mathrm{E}}$ showed slower migration on the gel than $L b \mathrm{ADH}^{\mathrm{WT}}$ (Fig. 2d). In SDS-PAGE, proteins with a lower pI might migrate slower due to stronger negative charge repulsion with SDS (Shirai et al. 2008).

The net charge and the ionization state of individual residues affect many aspects of protein behavior including protein structure, stability, solubility, and function (Shaw et al. 2001; Pace et al. 2009). The slightly different elution profiles of $L b \mathrm{ADH}^{\mathrm{K} 71 \mathrm{E}}$ and $L b \mathrm{ADH}^{\mathrm{WT}}$ in the sizeexclusion chromatography (Fig. 2b) support a structural change caused by the K71E mutation. Moreover, electrostatic effects dominate hydration, denaturation, protein assembly, allostery and salt bridges, thermal stability and enzyme catalysis (Perutz 1978; Matthew 1985). Many enzyme reactions proceed via charged transition states and therefore stabilization of charges can be a major catalytic factor (Russell and Fersht 1987). In the case of LbADH, Tyr155 is assumed to serve as a catalytic acid, which is deprotonated in the course of reduction and requires stabilization by the positively charged Lys 159 for this purpose (Schlieben et al. 2005; Jörnvall et al. 1995). The K71E exchange might have a positive influence on enzyme catalysis by stabilizing the charged transition state. Charged residues on the surface of proteins can also generate electrical potentials that extend many angstroms out into solution, enhancing substrate association rates and catalytic rates in enzymes (Sharp and Honig 1990). 
It is surprising that a single mutation on the protein surface, as is the case of the $L b \mathrm{ADH}^{\mathrm{K} 71 \mathrm{E}}$ variant, is sufficient to increase enzyme activity. Several studies have shown that it is possible to increase protein stability by improving electrostatic interactions among charged groups on the surface of folded proteins through multiple and even single mutations (Akke and Forsen 1990; Grimsley et al. 1999; Strickler et al. 2006; Gribenko et al. 2009). The main factors affecting stability are the relative free energies of the folded $\left(G_{f}\right)$ and the unfolded $\left(G_{u}\right)$ states. Protein stability is defined as the difference in Gibbs free energy, $\Delta G_{u}$, between the folded and the unfolded state. Specific algorithms have been developed to predict the effects of mutations on protein stability by estimating the changes in the difference in Gibbs free energy $(\Delta \Delta G)$ between the wild-type and the mutated enzyme. The mutated enzyme is more stable if $\Delta \Delta \mathrm{G}$ is positive. For the proteins $L b A D H^{\mathrm{WT}}$ and $\mathrm{LbADH}^{\mathrm{K} 71 \mathrm{E}}$ the servers SDM (Pandurangan et al. 2017) and I-Mutant 2.0 (Capriotti et al. 2005) both calculated $\Delta \Delta \mathrm{G}$ to be $+3.51 \mathrm{~kJ} / \mathrm{mol}$. The program iPTREE-STAB (Huang et al. 2007) predicted that the mutation K71E has a stabilizing effect without giving a concrete value for $\Delta \Delta G$. These predictions were supported by thermal shift assays revealing a slightly higher melting temperature for $L b \mathrm{ADH}^{\mathrm{K} 71 \mathrm{E}}$ than for $L b \mathrm{ADH}{ }^{\mathrm{WT}}$.

In summary, this study confirms the suitability of pSenSox for FACS-based high-throughput screening of ADH libraries to identify variants with improved catalytic properties. Although it is still unclear how the $\mathrm{K} 71 \mathrm{E}$ exchange positively influences the $\mathrm{K}_{\mathrm{M}}$ and $\mathrm{v}_{\max }$ values, the improved catalytic and stability properties the $L b \mathrm{ADH}^{\mathrm{K} 71 \mathrm{E}}$ variant should be favorable for biotechnological applications.

\section{Abbreviations \\ FACS: fluorescence-activated cell sorting; $L b A D H$ : alcohol dehydrogenase of Lactobacillus brevis; SDS-PAGE: sodium dodecyl sulfate-polyacrylamide gel electrophoresis.}

\section{Acknowledgements}

We are grateful to Prof. Wolfgang Kroutil (Department of Chemistry, University of Graz, Austria) for providing plasmid pASK-IBA5plus-Lbadh ${ }^{W T}$. We also would like to thank Christina Mack for protein purification in the final stages of this study.

\section{Authors' contributions}

$Y B$ constructed the $L b A D H$ library and performed the initial characterization of isolated clones in the BioLector after FACS screening. YB and AS performed the FACS screening experiments. LF and HvB helped to develop the FACS screening approach and to analyse the FACS data. AS constructed the plasmid pASK-IBA5plus-Lbadh ${ }^{K 71 E}$, carried out the purification of $\angle b A D H^{W T}$ and $\angle b A D$ $H^{\mathrm{K} 71 \mathrm{E}}$, and performed the biochemical characterization of these proteins. $\mathrm{HvB}$ performed the dynamic light scattering and the thermal shift assays. LS performed activity measurements in cell extracts and with purified enzymes. AS wrote the initial version of the manuscript and MBa performed a first revision of the manuscript. MBo wrote parts of the manuscript, revised and finalized the manuscript. All authors read and approved the final manuscript.

\section{Funding}

This work was funded by the German Federal Ministry of Education and Research (BMBF), funding code 031A095B, as part of the project "Molecular Interaction Engineering: From Nature's Toolbox to Hybrid Technical Systems (MIE)".

Availability of data and materials

The strains and plasmids described in this article are available from the corresponding author upon request.

\section{Ethics approval and consent to participate}

The article does not contain any studies with human participants or animals performed by any of the authors.

\section{Consent for publication}

Not applicable.

\section{Competing interests}

The authors declare that they have no competing interests.

Received: 20 August 2019 Accepted: 6 January 2020

Published online: 18 January 2020

\section{References}

Ager DJ, Prakash I, Schaad DR (1996) 1,2-Amino alcohols and their heterocyclic derivatives as chiral auxiliaries in asymmetric synthesis. Chem Rev 96:835-876

Akke M, Forsen S (1990) Protein stability and electrostatic interactions between solvent exposed charged side chains. Proteins 8:23-29

Bloch W (2006) Enzyme assays. High-throughput screening, genetic selection and fingerprinting. Anal Bioanal Chem 386:1583-1584

Breuer M, Ditrich K, Habicher T, Hauer B, Kesseler M, Sturmer R, Zelinski T (2004) Industrial methods for the production of optically active intermediates. Angew Chem Int Ed 43:788-824

Capriotti E, Fariselli P, Casadio R (2005) I-Mutant2.0: predicting stability changes upon mutation from the protein sequence or structure. Nucleic Acids Res 33:W306-W310

Dietrich JA, McKee AE, Keasling JD (2010) High-throughput metabolic engineering: advances in small-molecule screening and selection. Annu Rev Biochem 79:563-590

Döbber J, Pohl M, Ley SV, Musio B (2018) Rapid, selective and stable HaloTagLbADH immobilization directly from crude cell extract for the continuous biocatalytic production of chiral alcohols and epoxides. React Chem Eng 3:8-12

Eggeling L, Bott M, Marienhagen J (2015) Novel screening methods-biosensors. Curr Opin Biotechnol 35:30-36

Farinas ET, Bulter T, Arnold FH (2001) Directed enzyme evolution. Curr Opin Biotechnol 12:545-551

Gibson DG, Young L, Chuang R-Y, Venter JC, Hutchison CA, Smith HO (2009) Enzymatic assembly of DNA molecules up to several hundred kilobases. Nat Methods 6:343-345

Greenberg JT, Monach P, Chou JH, Josephy PD, Demple B (1990) Positive control of a global antioxidant defense regulon activated by superoxide-generating agents in Escherichia coli. Proc Natl Acad Sci USA 87:6181-6185

Gribenko AV, Patel MM, Liu J, McCallum SA, Wang C, Makhatadze GI (2009) Rational stabilization of enzymes by computational redesign of surface charge-charge interactions. Proc Natl Acad Sci USA 106:2601-2606

Grimsley GR, Shaw KL, Fee LR, Alston RW, Huyghues-Despointes BM, Thurlkill RL, Scholtz JM, Pace CN (1999) Increasing protein stability by altering long-range coulombic interactions. Protein Sci 8:1843-1849

Haberland J, Hummel W, Daussmann T, Liese A (2002) New continuous production process for enantiopure $(2 R, 5 R)$-hexanediol. Org Process Res Dev 6:458-462

Hall M, Bommarius AS (2011) Enantioenriched compounds via enzyme-catalyzed redox reactions. Chem Rev 111:4088-4110

Hanahan D (1983) Studies on transformation of Escherichia coli with plasmids. J Mol Biol 166:557-580 
Huang LT, Gromiha MM, Ho SY (2007) iPTREE-STAB: interpretable decision tree based method for predicting protein stability changes upon mutations. Bioinformatics 23:1292-1293

Hummel W (1999) Large-scale applications of NAD(P)-dependent oxidoreductases: recent developments. Trends Biotechnol 17:487-492

Jörnvall H, Persson B, Krook M, Atrian S, Gonzalez-Duarte R, Jeffery J, Ghosh D (1995) Short-chain dehydrogenases/reductases (SDR). Biochemistry 34:6003-6013

Kensy F, Zang E, Faulhammer C, Tan RK, Büchs J (2009) Validation of a highthroughput fermentation system based on online monitoring of biomass and fluorescence in continuously shaken microtiter plates. Microb Cell Fact 8:31

Krapp AR, Humbert MV, Carrillo N (2011) The soxRS response of Escherichia coli can be induced in the absence of oxidative stress and oxygen by modulation of NADPH content. Microbiology 157:957-965

Leuchs S, Greiner L (2011) Alcohol dehydrogenase from Lactobacillus brevis: a versatile robust catalyst for enantioselective transformations. Chem Biochem Eng 25:267-281

Liese A, Seelbach K, Wandrey C (2006) Industrial biotransformation. Wiley-VCH Verlag GmbH \& Co. KGaA, Weinheim

Liochev SI, Fridovich I (1992) Fumarase C, the stable fumarase of Escherichia coli, is controlled by the soxRS regulon. Proc Natl Acad Sci USA 89:5892-5896

Machielsen R, Looger LL, Raedts J, Dijkhuizen S, Hummel W, Hennemann H-G, Daussmann T, van der Oost J (2009) Cofactor engineering of Lactobacillus brevis alcohol dehydrogenase by computational design. Eng Life Sci 9:38-44

Mahr R, Frunzke J (2016) Transcription factor-based biosensors in biotechnology: current state and future prospects. Appl Microbiol Biotechnol 100:79-90

Matthew JB (1985) Electrostatic effects in proteins. Annu Rev Biophys Biophys Chem 14:387-417

Miroux B, Walker JE (1996) Over-production of proteins in Escherichia coli: mutant hosts that allow synthesis of some membrane proteins and globular proteins at high levels. J Mol Biol 260:289-298

Niefind K, Müller J, Riebel B, Hummel W, Schomburg D (2003) The crystal structure of $R$-specific alcohol dehydrogenase from Lactobacillus brevis suggests the structural basis of its metal dependency. J Mol Biol 327:317-328

Pace CN, Grimsley GR, Scholtz JM (2009) Protein ionizable groups: pK values and their contribution to protein stability and solubility. J Biol Chem 284:13285-13289

Pandurangan AP, Ochoa-Montano B, Ascher DB, Blundell TL (2017) SDM: a server for predicting effects of mutations on protein stability. Nucleic Acids Res 45:W229-w235

Perutz MF (1978) Electrostatic effects in proteins. Science 201:1187

Riebel, B. (1997) Biochemische und molekularbiologische Charakterisierung neuer mikrobieller NAD(P)-abhängiger Alkoholdehydrogenasen. Dissertation, Heinrich-Heine-Universität Düsseldorf, Germany
Rodriguez C, Borzecka W, Sattler JH, Kroutil W, Lavandera I, Gotor V (2014) Steric vs. electronic effects in the Lactobacillus brevis ADH-catalyzed bioreduction of ketones. Org Biomol Chem 12:673-681

Rogers JK, Taylor ND, Church GM (2016) Biosensor-based engineering of biosynthetic pathways. Curr Opin Biotechnol 42:84-91

Russell AJ, Fersht AR (1987) Rational modification of enzyme catalysis by engineering surface charge. Nature 328:496-500

Sambrook J, Russell D (2001) Molecular cloning. A laboratory manual. Cold Spring Harbor Laboratory Press, Cold Spring Harbor

Schlieben NH, Niefind K, Müller J, Riebel B, Hummel W, Schomburg D (2005) Atomic resolution structures of $R$-specific alcohol dehydrogenase from Lactobacillus brevis provide the structural bases of its substrate and cosubstrate specificity. J Mol Biol 349:801-813

Schrödinger LLC (2015) The PyMOL molecular graphics system. Version 1:8

Sharp KA, Honig B (1990) Electrostatic interactions in macromolecules: theory and applications. Annu Rev Biophys Biophys Chem 19:301-332

Shaw KL, Grimsley GR, Yakovlev Gl, Makarov AA, Pace CN (2001) The effect of net charge on the solubility, activity, and stability of ribonuclease Sa. Protein Sci 10:1206-1215

Shirai A, Matsuyama A, Yashiroda Y, Hashimoto A, Kawamura Y, Arai R, Komatsu Y, Horinouchi S, Yoshida M (2008) Global analysis of gel mobility of proteins and its use in target identification. J Biol Chem 283:10745-10752

Siedler S, Schendzielorz G, Binder S, Eggeling L, Bringer S, Bott M (2014) SoxR as a single-cell biosensor for NADPH-consuming enzymes in Escherichia coli. ACS Synth Biol 3:41-47

Spielmann A, Baumgart M, Bott M (2019) NADPH-related processes studied with a SoxR-based biosensor in Escherichia coli. MicrobiologyOpen 8:e785

Strickler SS, Gribenko AV, Gribenko AV, Keiffer TR, Tomlinson J, Reihle T, Loladze W, Makhatadze GI (2006) Protein stability and surface electrostatics: a charged relationship. Biochemistry 45:2761-2766

Tsaneva IR, Weiss B (1990) soxR, a locus governing a superoxide response regulon in Escherichia coli K-12. J Bacteriol 172:4197-4205

van Rossum T, Kengen SW, van der Oost J (2013) Reporter-based screening and selection of enzymes. FEBS J 280:2979-2996

Zhang R, Xu Y, Xiao R (2015) Redesigning alcohol dehydrogenases/reductases for more efficient biosynthesis of enantiopure isomers. Biotechnol Adv 33:1671-1684

Zheng YG, Yin HH, Yu DF, Chen X, Tang XL, Zhang XJ, Yue-Y P, Wang YJ, Liu ZQ (2017) Recent advances in biotechnological applications of alcohol dehydrogenases. Appl Microbiol Biotechnol 101:987-1001

\section{Publisher's Note}

Springer Nature remains neutral with regard to jurisdictional claims in published maps and institutional affiliations.

\section{Submit your manuscript to a SpringerOpen ${ }^{\circ}$ journal and benefit from:}

- Convenient online submission

- Rigorous peer review

- Open access: articles freely available online

- High visibility within the field

- Retaining the copyright to your article

Submit your next manuscript at springeropen.com 